REgULAR ARTiCLE

\title{
EFFECT OF BIO-STIMULATORS ON GROWTH AND YIELD OF COWPEA LEAVES (VIGNA UNGUICULATA WALP) PRODUCED IN JUJA AND KATUMANI IN KENYA
}

\section{JUDITH OYOO' ${ }^{*}$, EDWARD MAMATI ${ }^{2}$, PAUL KINOTI 2 , ELIJAH ATEKA², JAMES KARANJA3, MIRIAM JUDITH OTIPA ${ }^{3}$, LUSIKE WASILWA4}

${ }^{1}$ Department of Outreach and Partnerships, Potato Research Centre, Horticulture Research Institute, Kenya Agricultural and Livestock Research Organization (KALRO), Limuru, Kenya

${ }^{2}$ Department of Horticulture, Jomo Kenyatta University of Agriculture and Technology, Juja

3Kenya Agricultural and Livestock Research Organization, National Agricultural Laboratories Research Centre, Kabete

${ }_{4}^{4}$ Crop Systems Unit, Kenya Agricultural and Livestock Research Organization (KALRO)

\begin{abstract}
Bio-stimulators are organic products that have been found to enhance crop growth and productivity through mitigating against biotic and abiotic stresses. Four Cowpea varieties namely K80, M66, KVU 27-1 and Kenya Kunde; commercially released and adopted by local households for vegetable production were used to evaluate the impact of bio-stimulators on growth and leaf yield of cowpea in Juja and Katumani from May to July, 2013. The treatments were arranged in a factorial structure, laid out in an RCBD, which were combination of 9 levels of bio-stimulators, with the 4 cowpea varieties planted per site, and giving a total of 36 treatments for each site replicated 3 times. The plots measured $2.5 \mathrm{~m}$ by $2.5 \mathrm{~m}$ with spacing of $60 \mathrm{~cm}$ by $20 \mathrm{~cm}$. Parameters under investigation included germination rate, days to germination, plant height, and number of leaves produced and number of nodules formed. Cultural practices such as weeding and pest control were done as need arose. The results showed that there were significant differences in days to germination, germination rate, plant population, chlorophyll levels, leaf weight, plant height and leaf area but not in leaf area between Juja and Katumani. Earliest germination and highest leaf weight were in Katumai whereas highest plant population, germination rate and chlorophyll levels and leaf area were in Juja. Humates improved germination rate, plant height, leaf weight and nodule development in Juja while seaweed extracts improved days to germination, germination rate, plant height, leaf yield, leaf weight and nodule formation in Katumani. Interaction between site and bio-stimulators was recorded in germination rate, days to germination, plant population and in number of leaves produced. Therefore, bio-stimulators should be adopted in production of cowpea leaves particularly offseason for food and nutritional security and increasing household incomes in Kenya
\end{abstract}

Keywords: Humates, seaweed extracts, biotic and abiotic stresses, nodule, local households, food security

\section{INTRODUCTION}

Bio-stimulators are natural substances that stimulate plant processes at very low concentrations They are derived from plants and animals and contain amino acids, low molecular weight polypeptides, vitamins, enzymes, hormones (cytokinins, auxins and gibberellins), sugars, betaines and antioxidants $(1,2)$. They are either single or multi-ingredient preparations supporting biochemical processes therefore enhancing plants' resistance to biotic and abiotic stresses upon application without interfering with the inherent plant processes and pathways (3). Biostimulators have been found to influence plant processes such as photosynthesis, respiration and nutrient availability $(5,6)$, inhibit heavy metals uptake by plants (1) and improve plant tolerance to pests through invoking a systemic acquired resistance correlated with accumulation of parthenogenesis related proteins (PR) (3).

Studies have shown that bio-stimulators applied on different crops have positively influenced crop growth thereby leading to better yields. Bio-stimulators sprayed on tomato plants in vegetative stage increased fruit yield by $30 \%$ and the number of flowers and seeds per flower head in Marigold seedlings by 50\% (7). Other biostimulators such as Maxi crop® (Ascophyllum nodosum)

Received 11 September 2017; Accepted 10 December 2017

*Corresponding Author

Judith Oyoo

Department of Outreach and Partnerships, Potato Research Centre, Horticulture Research Institute, Kenya Agricultural and Livestock Research Organization (KALRO), Limuru, Kenya

Email: judithilukol@gmail.com

( This article is open access and licensed under the terms of the Creative Commons Attribution License (http://creativecommons.org/licenses/by/4.o/) which permits unrestricted, use, distribution and reproduction in any medium, or format for any purpose, even commercially provided the work is properly cited. Attribution - You must give appropriate credit, provide a link to the license, and indicate if changes were made. 
and (Ecklonia maxima) enhanced yields in lettuce, barley pepper and beans by $24 \%$ (7). Application of biostimulators to a cabbage crop led to increased plant growth and activity of microbes antagonistic to Pythium ultimum that causes damping-off disease and pests (aphids) generally avoided plants treated with seaweed extracts (8). In Kenya use of bio-stimulators in potato production led to $15 \%$ increase in marketable tuber yield in the high potential areas (9). Use of bio-stimulators in Kenya has been done though on a small scale and only in high potential areas, despite the fact that they have been found to be more effective in abiotic and biotic stressed environments. Cowpea is a popular traditional vegetable crop in Kenya whose production is exponentially rising, hence chosen as a model crop. Cowpea is also a popular leafy food legume with high source of dietary protein and nutritious fodder in the semi-arid tropics (10). Cowpea seeds contain 21-33\% proteins while the leaves contain 29$43 \%$ vegetable proteins on a dry weight basis thus provides protein to majority of the rural and urban poor population that cannot afford animal proteins, hence a potential crop for attaining nutritional security (11). Bio-stimulators have been found globally to have great potential in enhancing crop productivity especially vegetable production but little work has been done with them in Kenya on crop production in harsh environments such as drought, hence forming the basis of this study.

\section{MATERIALS AND METHODS}

\section{Experimental site}

The study was conducted in Katumani, Machakos County and Jomo Kenyatta university of Agriculture and Technology (JKUAT) in Kiambu County from May to July 2013. JKUAT lies at an altitude of $1525 \mathrm{~m}$ above sea level and latitude of $1^{\circ} 10^{\prime} 48^{\prime} \mathrm{S}$, long. $37^{\circ} 07^{\prime} 12^{\prime}$ Eand is located in the LH 2. Rainfall amount in this area ranges from $600-800$ $\mathrm{mm}$ annually with average temperatures of $25{ }^{\circ} \mathrm{C}$. (12). Katumani lies at an altitude of $1575 \mathrm{~m}$ above sea level and latitude of $1^{\circ} 35^{\prime} \mathrm{S}$ and $37^{\circ} 14^{\prime} \mathrm{E}$ in agro-ecological zone IV. Rainfall amount in the area ranges from 500-700 $\mathrm{mm}$ per year with mean 4 commercially released and locally adopted cowpea varieties identified for leaf and grain production were selected namely K80, M66, KVU 27-1 and Kenya Kunde. K80, M66 and KVU 27-1 were obtained from the Basic Seed Unit of Kenya Agricultural and Livestock Research Organization (KALRO) Katumani while Kenya Kunde was bought from Agrochemical shop.

\section{Test crop}

\section{Experimental design}

Land was ploughed and harrowed and plots measuring $2.5 \mathrm{~m}$ by $2.5 \mathrm{~m}$ were prepared. Planting was done at a spacing of $60 \mathrm{~cm}$ by $20 \mathrm{~cm}$ giving a population of 96,00oplants/ha (13). The layout was a combination of the 4cowpea varieties, planted in 2 sites and the 9 levels of bio-stimulators giving a total of 36 treatments for each replicate; replicated thrice. Bio-stimulators were applied at planting except for foliar sprays which were done from 3 leaf stage up to flowering stage. All cultural practices were done as need arose (13).

\section{Data analysis}

Data was analyzed using GenStat statistical package 12th edition to determine interaction between treatments (14). Treatments were analysed using ANOVA while Separation of means was done by the Fisher's protected Least Significant Difference (LSD) test at $5 \%$ confidence interval.

\section{RESULTS}

The results showed that there were significant differences between Juja and Katumani in germination rate, days to germination, plant count, chlorophyll levels, plant height, leaf weight, leaf yield and number of nodules formed but not in stem thickness, leaf area or root length at $\mathrm{P} \leq 0.05$ (table 1; Figs 2and 3). Days to germination, rate of germination, survival rate, chlorophyll levels, leaf weight, and leaf area were higher in Juja than in Katumani (table 1). Plant height was also higher in Juja than in Katumani from week 1 to 8 (fig. 2)

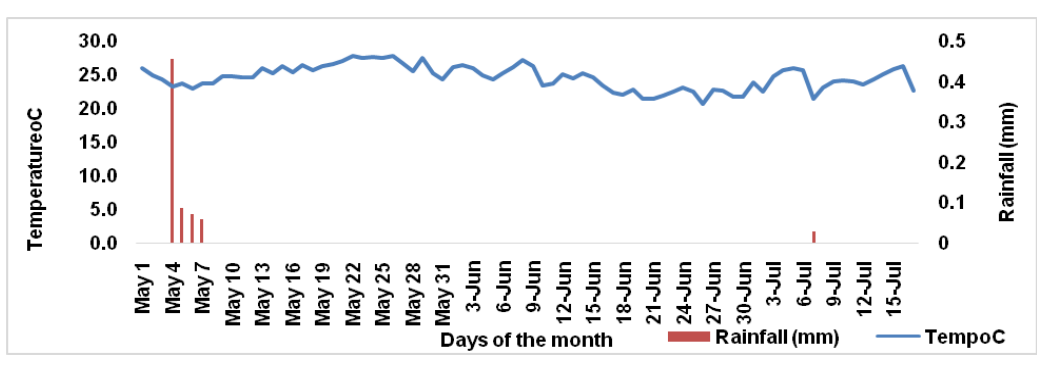

Fig. 1a: Rainfall and temperature in katumani from may to july

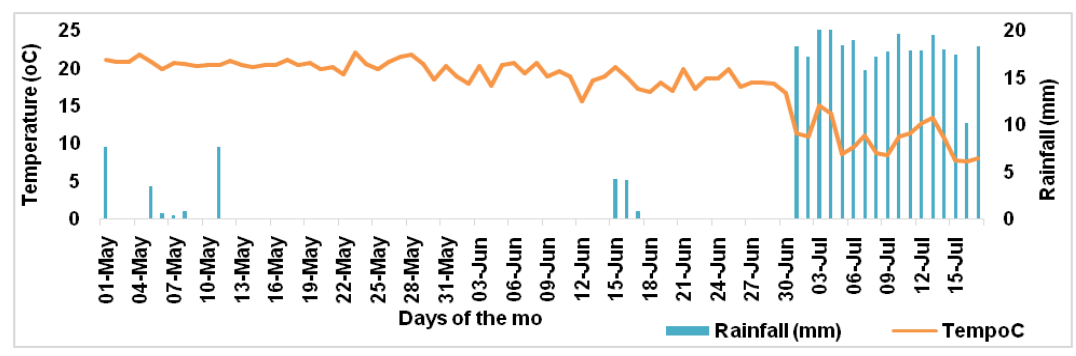

Fig. 1b: Rainfall and temperature in juja from may to july 
Table 1: Performance of parameters between Juja and Katumani

\begin{tabular}{lllllll}
\hline Site & $\begin{array}{l}\text { Days to } \\
\text { germination }\end{array}$ & $\begin{array}{l}\text { Rate of } \\
\text { germination \% }\end{array}$ & $\begin{array}{l}\text { Survival } \\
\text { rate }\end{array}$ & $\begin{array}{l}\text { Chlorophyll } \\
\text { levels }\end{array}$ & $\begin{array}{l}\text { Leaf weight } \\
(\mathbf{g})\end{array}$ & $\begin{array}{l}\text { Leaf area } \\
\left(\mathbf{c m}^{2}\right)\end{array}$ \\
\hline Juja & $8 b$ & $60 a$ & $70.4 a$ & $54.4 a$ & $1.6 b$ & $39.2 a$ \\
Katumani & $5 a$ & $29.2 b$ & $34.4 b$ & $48.9 b$ & $2.2 a$ & $34.5 a$ \\
Mean & 6 & 45 & 52.4 & 51.6 & 1.9 & 36.8 \\
LSD & 0.8 & 4.9 & 6.1 & 2.7 & 0.2 & 5.1 \\
P & $<.001$ & $<.001$ & $<.001$ & $<.001$ & $<.001$ & 0.07 \\
\hline
\end{tabular}

Means followed by the same letter are not significantly different at $\mathrm{P} \leq 0.05$

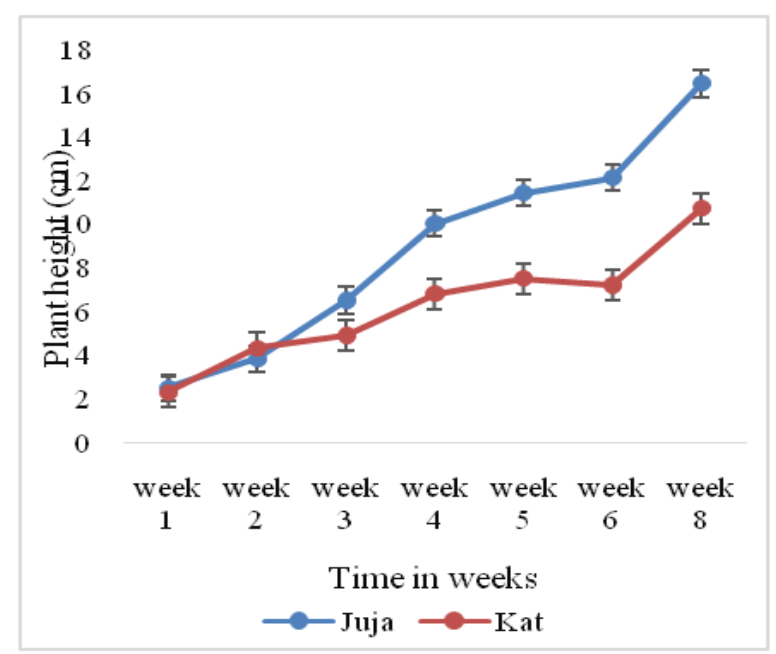

Fig. 2: Plant height in Juja and Katumani

Bio-stimulators were significantly different between Juja and Katumani in germination rate, days to germination, plant count, leaf area, leaf yield and nodulation but not in chlorophyll levels, plant height, stem thickness and leaf weight at $\mathrm{P} \leq 0.05$ (table 2). Juja had the highest rate of germination, survival rate, leaf area, leaf weight and chlorophyll levels (tables 2-3). Earliest germination was in Katumani. SWE basal application caused earliest germination in both sites, although both bio-stimulators caused early germination also.

Days to germination: SWE caused early germination of $5 \mathrm{~d}$ as compared to control and humates (11 d) in Juja while in Katumani, in $4 \mathrm{~d}$.
Germination rate: Highest germination rate was in humates in Juja and SWE basal application and foliar in Katumani (table 2).

Plant count: Juja had the highest number of plants established of $70 \pm 6.7$ compared to Katumani with $34 \pm 7.0$. Humates had the highest number of plants in Jujaof $81 \pm 5.6$ while SWE basal application and foliar spray in Katumaniwith $72 \pm 6.6$ (table 3).

Leaf area: The highest leaf area was recorded in humates with $50.7 \pm 4.4 \mathrm{~cm}^{2}$ in Jujawhile in Katumani54.1 \pm 1.8 .

Leaf weight: The highest leaf weight was recorded in humates (Katumani) with 2.5 $\pm 0.3 \mathrm{~g}$ (table 3 ).

Chlorophyll: Chlorophyll levels were highest in humates with SWE foliar spray in Juja $(56.6 \pm 1.1)$ while in Katumani

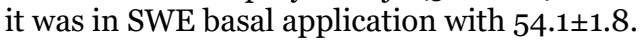

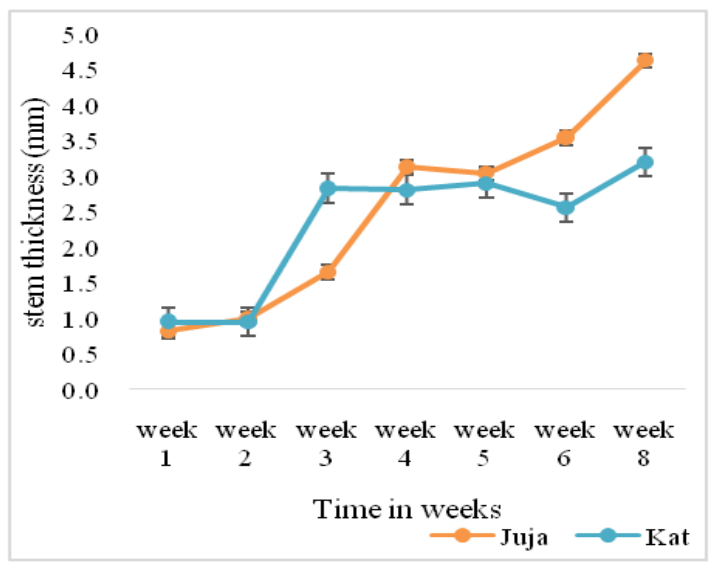

Fig. 3: Stem thickness in Juja and Katumani

Table 2: Germination rate, days to germination and plant count in bio-stimulators

\begin{tabular}{|c|c|c|c|c|c|c|}
\hline \multirow[t]{2}{*}{ Treatment } & \multicolumn{2}{|c|}{ Rate of germination } & \multicolumn{2}{|c|}{ Days to germination } & \multicolumn{2}{|c|}{ Plant count } \\
\hline & Juja & Katumani & Juja & Katumani & Juja & Katumani \\
\hline Humates & $67 \pm 4.6$ & $15 \pm 5 \cdot 3$ & $11 \pm 0.19$ & $4 \pm 0.44$ & $81 \pm 5.6$ & $17 \pm 6.5$ \\
\hline Humates+SWE basal application & $60 \pm 5.1$ & $37 \pm 8.2$ & $5 \pm 0.27$ & $4 \pm 0.40$ & $70 \pm 7.0$ & $43 \pm 9.4$ \\
\hline Humates+SWE basalapplication+SWE foliar & $56 \pm 5 \cdot 5$ & $40 \pm 4.8$ & $5 \pm 0.36$ & $4 \pm 0.00$ & $61 \pm 8.3$ & $47 \pm 5.4$ \\
\hline Humates+SWE foliar & $64 \pm 4.8$ & $15 \pm 7.1$ & $11 \pm 0.26$ & $6 \pm 0.86$ & $76 \pm 5.8$ & $17 \pm 8.2$ \\
\hline SWE basal application & $61 \pm 5.5$ & $44 \pm 6.6$ & $5 \pm 0.26$ & $4 \pm 0.00$ & $72 \pm 6.4$ & $52 \pm 7.1$ \\
\hline SWE basalapplication+SWE foliar & $51 \pm 4.8$ & $60 \pm 5.6$ & $5 \pm 0.37$ & $4 \pm 0.08$ & $60 \pm 6.9$ & $72 \pm 6.6$ \\
\hline SWE foliar & $63 \pm 4 \cdot 4$ & $23 \pm 6.1$ & $11 \pm 0.36$ & $5 \pm 0.27$ & $74 \pm 6.4$ & $27 \pm 7.3$ \\
\hline Biofix & $62 \pm 5.1$ & $3 \pm 1.6$ & $10 \pm 0.19$ & $6 \pm 0.94$ & $70 \pm 7.6$ & $4 \pm 1.9$ \\
\hline Control & $59 \pm 5.2$ & $27 \pm 8.6$ & $11 \pm 0.19$ & $7 \pm 1.50$ & $71 \pm 6.2$ & $32 \pm 10.3$ \\
\hline Mean & $61 \pm 5.2$ & $29 \pm 8.6$ & $8 \pm 0.29$ & $4 \pm 3 \cdot 75$ & $70 \pm 6.7$ & $34 \pm 7.0$ \\
\hline $\mathrm{P}$ & $<.001^{* * *}$ & & $<.001^{* * *}$ & & $<.001^{* * *}$ & \\
\hline
\end{tabular}

Means **-highly significant, *-significant, NS-not significant at $\mathrm{P} \leq 0.05$; with SE separation at $\mathrm{P}<0.05$ 
Table 3: Leaf weight, leaf area and chlorophyll levels between bio-stimulators

\begin{tabular}{|c|c|c|c|c|c|c|}
\hline \multirow[t]{2}{*}{ Treatments } & \multicolumn{2}{|c|}{ leaf weight (g) } & \multicolumn{2}{|c|}{ leaf area $\left(\mathrm{cm}^{2}\right)$} & \multicolumn{2}{|c|}{ Chlorophyll levels } \\
\hline & Juja & Katumani & Juja & Katumani & Juja & Katumani \\
\hline Humates & $2.1 \pm 0.2$ & $2.4 \pm 0.5$ & $49.4 \pm 4.7$ & $42.6 \pm 5.6$ & $54.0 \pm 1.3$ & $41.6 \pm 1.3$ \\
\hline Humates+SWE basal application & $1.4 \pm 0.2$ & $2.4 \pm 0.3$ & $33.7 \pm 4.8$ & $25.8 \pm 5.2$ & $52.2 \pm 1.6$ & $51.3 \pm 4.8$ \\
\hline Humates+SWE basal application+SWE foliar & $1.5 \pm 0.2$ & $2.1 \pm 0.3$ & $40.0 \pm 6.1$ & $34.4 \pm 5.5$ & $54.1 \pm 1.1$ & $51.7 \pm 2.4$ \\
\hline Humates+SWE foliar & $2.0 \pm 0.2$ & $2.1 \pm 0.4$ & $50.7 \pm 4.4$ & $40.6 \pm 3.3$ & $56.6 \pm 1.1$ & $46.9 \pm 0.9$ \\
\hline SWE basal application & $1.4 \pm 0.2$ & $2.4 \pm 0.3$ & $36.7 \pm 5.2$ & $33.8 \pm 6.6$ & $55 \cdot 3 \pm 1.3$ & $54.1 \pm 1.8$ \\
\hline SWE basal application+SWE foliar & $1.5 \pm 0.3$ & $2.5 \pm 0.3$ & $35.8 \pm 8.0$ & $41.9 \pm 9.4$ & $55.1 \pm 1.1$ & $53 \cdot 5 \pm 1.3$ \\
\hline SWE foliar & $1.7 \pm 0.2$ & $2.1 \pm 0.2$ & $39.9 \pm 5.7$ & $37.9 \pm 6.1$ & $53.6 \pm 1.1$ & $43 \cdot 3 \pm 2.3$ \\
\hline Biofix & $1.3 \pm 0.2$ & $2.0 \pm 0.3$ & $32.1 \pm 4.9$ & $24.2 \pm 4.1$ & $53.8 \pm 0.7$ & $43.5 \pm 0.9$ \\
\hline Control & $1.5 \pm 1.0$ & $1.9 \pm 1.0$ & $34.4 \pm 3.5$ & $29.2 \pm 4.9$ & $54.9 \pm 1.2$ & $50.8 \pm 1.9$ \\
\hline Mean & $1.6 \pm 0.1$ & $2.1 \pm 0.1$ & $34.5 \pm 1.8$ & $29.2 \pm 2.0$ & $54.4 \pm 0.8$ & $48.9 \pm 1.4$ \\
\hline LSD & 0.7 & & 15.9 & & 8.0 & \\
\hline
\end{tabular}

**-highly significant, *-significant, NS-not significant at $\mathrm{P} \leq 0.05$; with SE separation at $\mathrm{P}<0.05$

Nodules: Bio-stimulators influenced nodulation from weeks 5 to 8 in Juja but in Katumani only up to week 6 . Highest number of nodules were recorded in

Table 4: Nodulation in bio-stimulators between Juja and Katumani

\begin{tabular}{|c|c|c|c|c|c|c|}
\hline & \multicolumn{2}{|c|}{ Week 5} & \multicolumn{2}{|c|}{ Week 6} & \multicolumn{2}{|c|}{ Week 8} \\
\hline & Juja & Katumani & Juja & Katumani & Juja & Katumani \\
\hline Humates & $6 a$ & $6 a b$ & $9 a$ & $2 a b$ & $21 a b$ & $11 a$ \\
\hline Humates+SWEbasal application & $5 a$ & $7 a b$ & $11 a$ & $3 a b$ & $10 b c$ & $3 a$ \\
\hline Humates+SWE basal application+SWE foliar spray & $6 a$ & $11 a$ & $8 a$ & $3 a b$ & $18 a b c$ & $2 a$ \\
\hline Humates+SWE foliar spray & $4 a$ & $6 a b$ & $9 a$ & $1 b$ & $19 a b c$ & $4 a$ \\
\hline SWE basal application & $6 a$ & $9 a b$ & $9 a$ & $6 a$ & $17 a b c$ & $2 a$ \\
\hline SWE basal application+SWEfoliar spray & $8 a$ & $12 a$ & $9 a$ & $4 a b$ & $8 c$ & $3 a$ \\
\hline SWE foliar & $5 a$ & $5 a b$ & $9 a$ & $2 a b$ & $12 a b c$ & $6 a$ \\
\hline Biofix & $4 a$ & $2 b$ & $9 a$ & $1 b$ & $11 a b c$ & $7 a$ \\
\hline Control & $5 a$ & $7 a b$ & $8 a$ & $3 a b$ & $22 a$ & $10 a$ \\
\hline Mean & 5.4 & 7.2 & 9 & 2.7 & $15 \cdot 3$ & $5 \cdot 3$ \\
\hline Lsd & 6 & & 5 & & 6 & \\
\hline$P$ value & $0.04^{*}$ & & $<.00$ & & $<.001^{*}$ & \\
\hline
\end{tabular}

**-highly significant, *-significant, NS-not significant at $\mathrm{P} \leq 0.05$; Means followed by the same letter are not significantly different at $\mathrm{P} \leq 0.05$

Leaf yield: Production of leaves was highest in Juja mainly in humates from week 3 to 8 . Katumani had the highest number of leaves produced in SWE basal application with foliar spray (fig. 3i-iii). Katumani produced the highest number of leaves in week 3 , though by a leaf (fig. 3i)

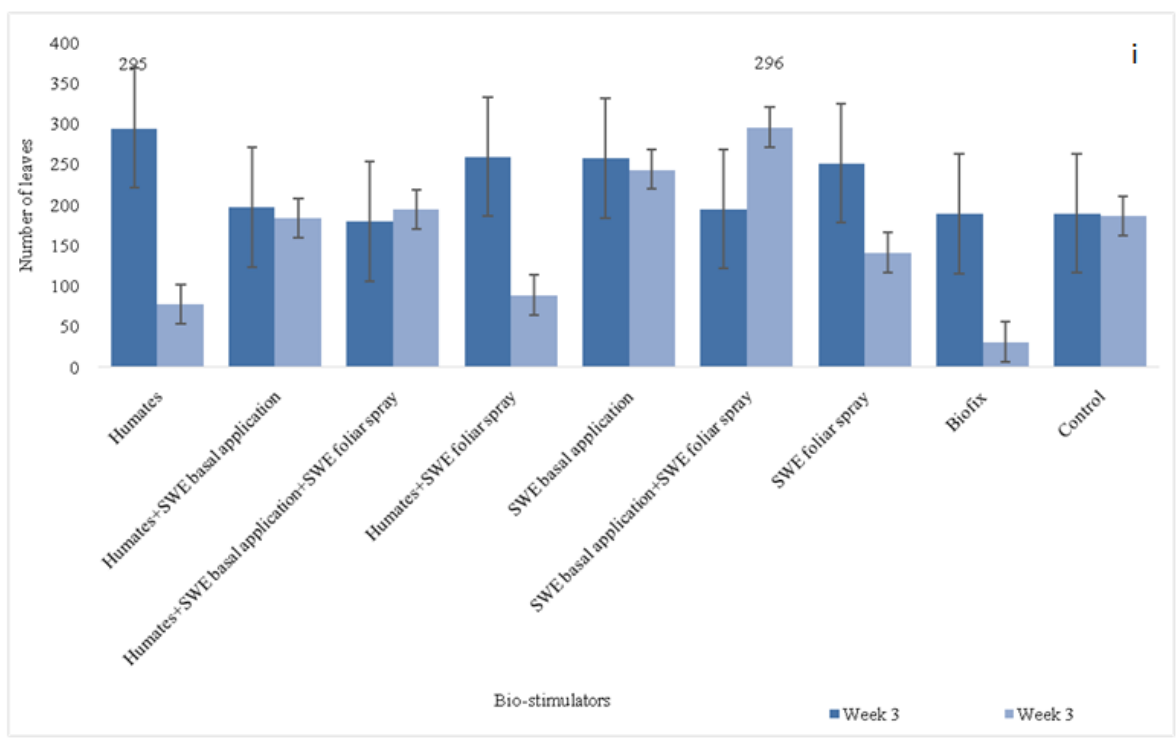


J. Phytol. 2017, 9: 15-23

http://updatepublishing.com/journal/index.php/jp
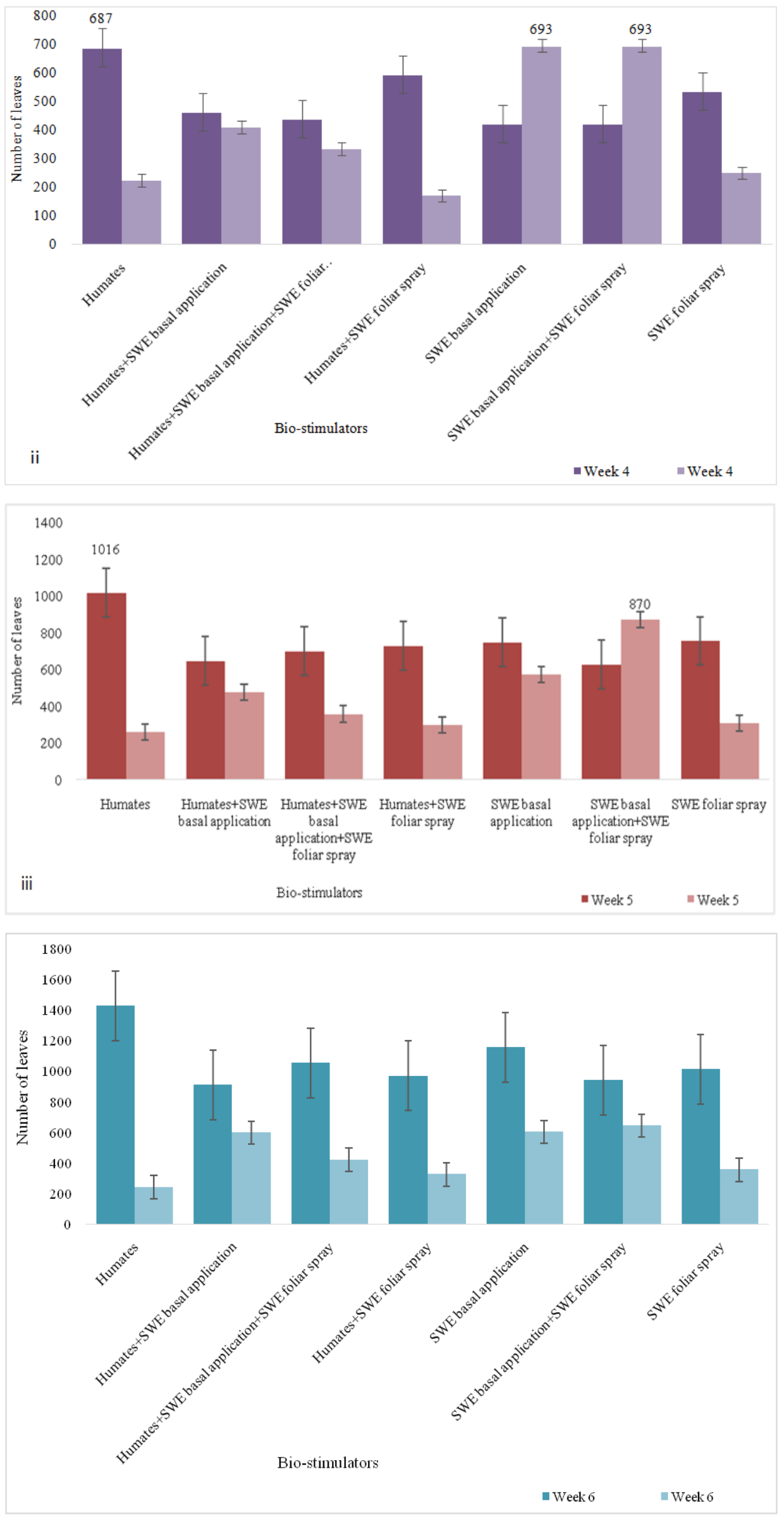


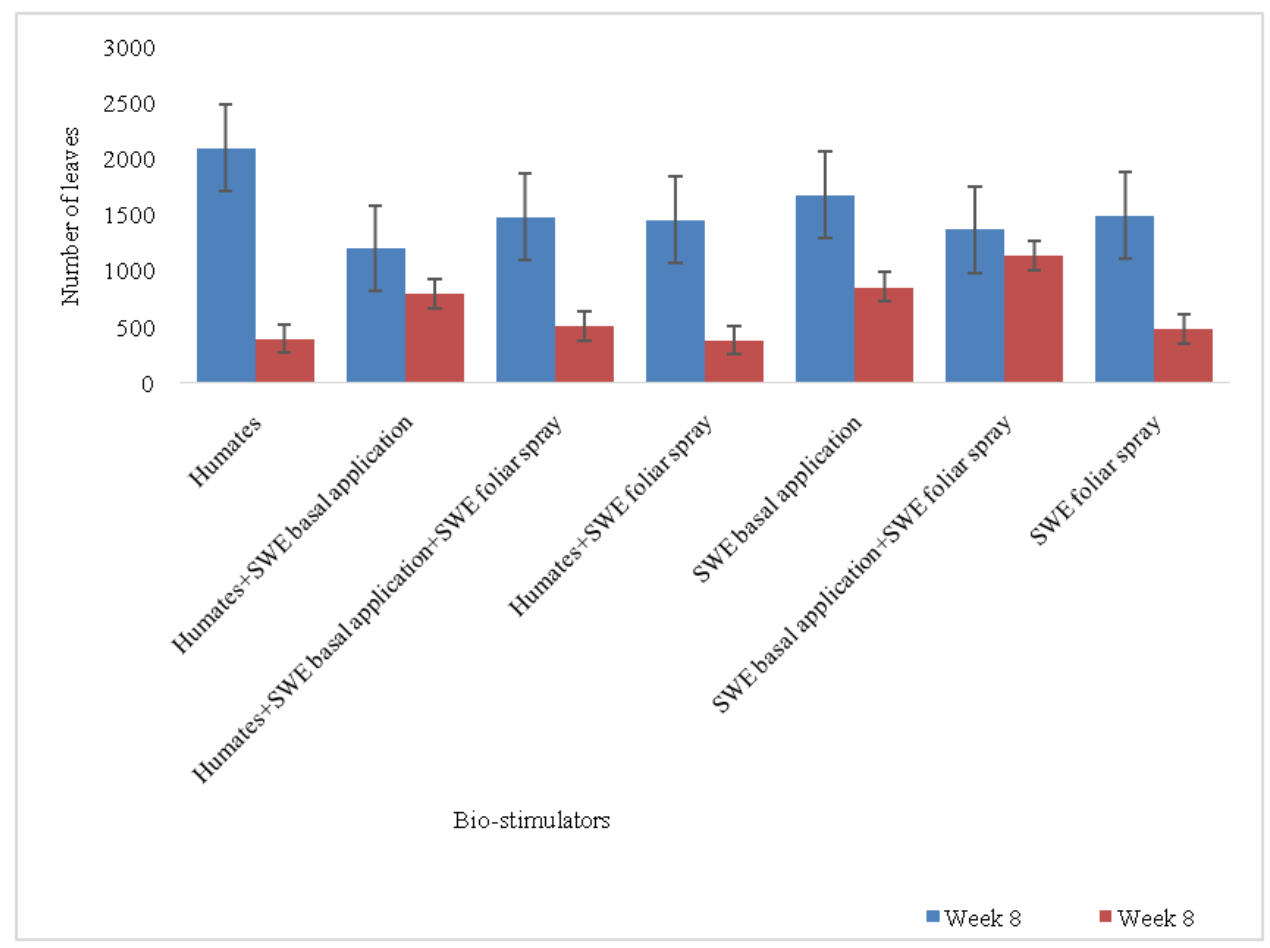

Fig. 4: Number of leaves produced in bio-stimulators from week 3(i) to week 8 (v), SE of means at $P \leq O . O 5$, Varieties were significantly different between Juja and Katumani in germination rate, plant count and number of leaves produced at $\mathbf{P} \leq \mathbf{0 . 0 5}$ (table 4)

Table 4: Performance of varieties between Juja and Katumani

\begin{tabular}{llllll}
\hline Varieties & Week 3 & Week 4 & Week 5 & Week 6 & Week 8 \\
\hline K80 & 220 & 549 & 712 & 894 & 1378 \\
Kenya Kunde & 189 & 356 & 511 & 607 & 870 \\
KVU 27-1 & 167 & 341 & 431 & 509 & 717 \\
M66 & 195 & 420 & 609 & 840 & 1106 \\
Mean & 193 & 416 & 566 & 713 & 1018 \\
LSD & 47.8 & 93.6 & 141 & 181 & 280 \\
P & $<.001^{* * *}$ & $<.001^{* * *}$ & $<.001^{* * *}$ & $<.001^{* * * *}$ & $<.001^{* * *}$ \\
\hline
\end{tabular}

*****-highly significant, ${ }^{*}$-significant, NS-not significant at $P \leq 0.05$; with SE separation at $P<0.05$

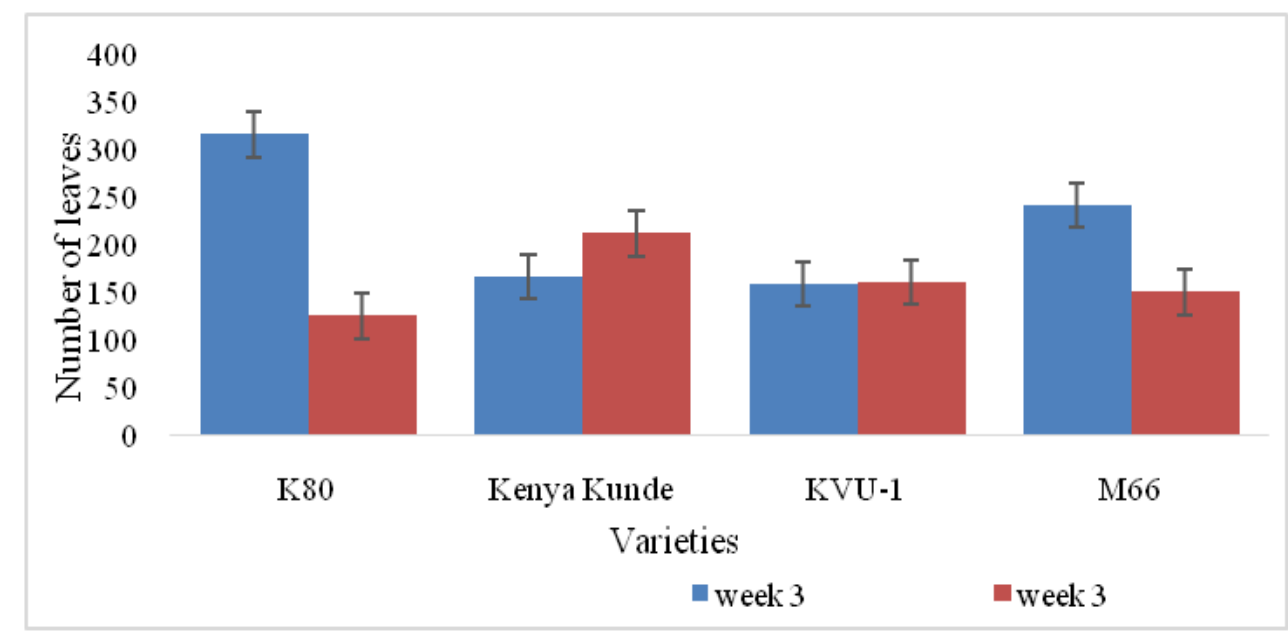



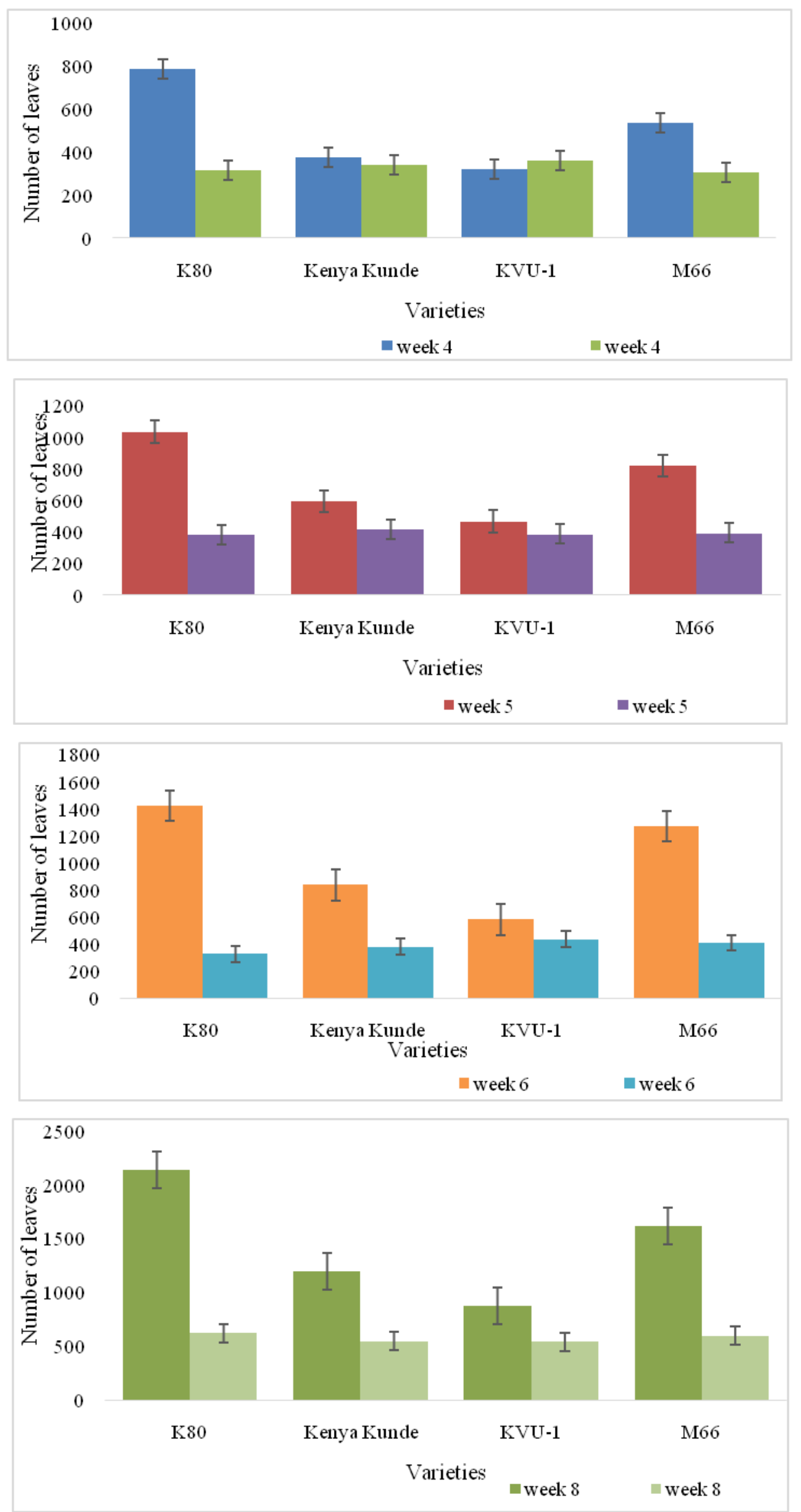

Fig. 5: Number of leaves produced in Varieties from week 3(i) to week 8 (v), SE of means at P $\leq$ o.o5 


\section{DISCUSSION}

The results described in this study showed that biostimulators which are humates and seaweed extracts(SWE) of Ecklonia maxima improved cowpea growth, leaf production and leaf weight (7). The humates and seaweed extracts applied at planting led to early germination and higher germination rates by between 9$52 \%$ in all the varieties (table $1 \mathrm{~b}$ ) agreeing with findings of some researchers (7) that bio-stimulators applied at an early stage tended to enhance germination and plant growth. Some studies done proved that potassium humates and soluble potash present in seaweed extracts caused early germination and increased germination rate of between $37-64 \%$ in Okra $(25,15)$. Plant height (fig. 2), leaf weight and leaf yield (Tables 2and3) were observed to be higher in Juja in humates while in Katumani in SWE treatments. Humates and SWE have been found to contain substantial quantities of cytokinins, carbohydrates, amino acids, vitamins, minerals, micro nutritive elements, betains and anti-oxidants such as phenolic acids and flavonoids which upon application exogenously either during planting as drench or foliar spray triggered higher levels of endogenous cytokinins and auxins that led to early germination, higher root and shoot growth, nutrient mobilization, increase in root mass, photochemical efficiency, anti-oxidant levels and anti-senescence properties of various turf grass species during abiotic stresses $(8,16 ; 2 ; 17 ; 18)$. Studies done previously showed $20 \%$ seaweed extracts of Rosenvigea intricate increased the length and weight of Cyamopsis tetragonoloba and watermelon compared to controls (19, 20 and 21). Similar observations were made in studies in Cajanus cajan, Vigna radiate and Dolichos biflorus, potatoes (Solanum tuberosum) (9) and Diptychandra aurantiaca (22) where application of bio-stimulators at very low concentrations led to higher germination and growth compared to controls (23). Foliar application of SWE increased length, diameter and fruit yields as well as early maturity in pepper (8), cucumber (2) and tomatoes (24) because of rapid absorption of nutrients which are directly and quickly incorporated into the plant metabolism $(25,6)$. Humates have been found to trigger greater root mass as a result of direct contact with the roots leading to initiation of root hypocotyl segments in legumes (7). Further studies have shown that drought-stressed plant treated with both humic acids and seaweed extract increased root mass by $21-68 \%$, foliar tocopherol by $110 \%$ and endogenous zeatinriboside by $38 \%(2 ; 18)$. Bio-stimulators influenced nodulation in weeks 5 and 6 in Juja and weeks 5 to 7 in Katumani, with the most number of nodules recorded in untreated in week 7 with 22 (table 3). Biosynthesis of auxins and cytokinins has been found to contribute significantly to bacterial growth in the rhizosphere as a result of rapid cell division and nitrogen fixing nodule formation, rapid growth of primary roots and branching $(18,27)$. Therefore, application of bio-stimulators could have promoted biosynthesis of cytokinins and auxins that could have led to more nodules formed. Due to rainfall failure and hence insufficient moisture in Katumani compared to Juja as observed from the weather report (fig. 1aandb), nodules formed were more in Juja. Nodulation is an energy intensive process requiring sufficient nutrients and moisture for the rhizobia to survive in the soil until they infect the roots, hence insufficient moisture could have been responsible for low number of nodules in Katumani probably due to low survival rate of Rhizobia in the soil (7). Similar results were found by Royarath et al.
(26) with extracts of $A$. nodosum on Arabidopsis and $R$. inricata on Abelmoschus esculentus. Biofix as a commercial bio-stimulator did not have great impact probably also due to harsh environmental conditions for any significant impact to be recorded.

\section{CONCLUSION}

Bio-stimulators have the potential to enhance germination and establishment, increase crop growth vigour and eventually improve cowpea leaf yields. Humates performed best in Juja while in Katumani the seaweed extracts (SWE). K80 produced more foliage than all the other varieties.

\section{RECOMMENDATION}

Bio-stimulators should be used to grow cowpea in environmentally harsh conditions for increased food security and wealth creation through sale of surplus.

\section{ACKNOWLEDGEMENT}

The authors are grateful to Jomo Kenyatta University of Agriculture and Technology (JKUAT) and Kenya Agricultural Livestock Research Organization(KALRO) for funding the project and KALRO Katumani for giving land to do the study. In addition, the authors acknowledge the assistance given by the staff of both institutions in carrying out this study.

\section{REFERENCES}

1. Starck Z. Growing assistant. Application of growth regulators and bio-stimulators in modern plant cultivation (in Polish). RolnikDziercawca 2005;2:74-76

2. Thirumaran, G, Arumugam M, Arumugam R, and Anantharaman P. Effect of seaweed liquid fertilizer on growth and pigment concentration of Abelmoschusesculentus (L) medikus. AmericanEurasian Journal of Agronomy. 2009;2:57-62. IDOSI Publications

3. Wojdyła AT. Effectiveness of Atonik SL in the control of powdery mildew, black spot, and rust. Folia Hort. Ann. 2004;16:175-181.

4. Ramya SS, Nagaraj S and Vijayanand N. Influence of seaweed liquid extracts on growth, biochemical and yield characteristics of Cymopsis tetragonolaba (L) Taub. Journal of Phytology. 2011;3:37-41.

5. KhanW, RayirathUP, SubramanianS, JiteshMN, RayorathP, Prithiviraj B. Seaweed extracts as biostimulants of Plant growth and development. Review. Journal of Plant growth and Regul.2009;28:386-399.

6. Craigie JS. Seaweed Extract Stimuli in Plant Science and Agriculture. Journal of Applied Phycology 23. 2011, 371-393.

7. KARITigoni. Annual Report. National Potato Research Centre, Tigoni. 2005. Kenya Agricultural Research Institute (KARI).

8. Singh BB, Ajeigbe HAA, Tarawali SAT, FernandezRivera SF and Abubaka MA. Improving the production and utilization of cowpea as food and fodder. Field Crops Research. 2003;84:169-177

9. Ngugi I K, Gitau R and Nyoro J. Access to High Value markets by smallholder farmers of african indigenous vegetables in Kenya. 2007. Re-governing markets Innovative Practice Series/IED London.

10. Jaetzold R, Schmidt H, Hornetz B, Shisanya C. Farm Management Handbook of Kenya. Vol. II. Natural Conditions and Farm Management Information. 2nd 
Edition. Part B. Central Kenya. Subpart B2. Ministry of Agriculture, Nairobi, Kenya. 2006

11. Karanja DR, Githunguri CM, M'Ragwa L, Mulwa D, and Mwiti, S. Variety, Characteristics and Production Guidelines of Traditional Food Crops. 2006. KARI Katumani Research Centre.

12. GenStat. GenStat for Windows. 2012. Lawes Agricultural Trust, Rothamsted Experimental Station, Harpenden, UK

13. Patil RB, Kadam AS. Wadje SS. Role of potassium humates on growth and yield of soybean and black gram. International Journal of Pharma and Biosciences.2011;2:242-246

14. Babaji BA, Amans EB, Falaki AM, Chiezey UF, Mahmud M, Mahadi MA. and Muhammad AA. Contributions of shoot N, P and $\mathrm{K}$ to tuber yield of Irish potato (Solanum tuberosum L.) at Samaru, Nigeria. Journal of Agricultural and Biological Science. 2007;2:4-5

15. Zhang X, EH Ervin, and RE Schmidt. Physiological effects of liquid applications of a seaweed extract and humic acid on creeping bentgrass. J. Am. Hort. Sci. 2003;128:492-496

16. Chojnaka K, Saeid A, Witkowska Z ,Tuhy, L Biologically active Compounds in Seaweed ExtractsThe Prospects for Application. The Open Access Conference Proceeding Journal. 2012;3:20-28

17. Fan Di, D Mark Hodges, Christopher W Kirby, Xiuhong Ji, and Steven J. Locke. Commercial extract of the brown seaweed Ascophyllum nodosum enhances phenolic antioxidant content of spinach (Spinacia oleracea L.) which protects Caenorhabditis elegans against oxidative and thermal stress. Food Chemistry. 2011;124:195-202. Publisher

18. Sivasankari SV Venkatesalu, M Anantharaj and M Chandrasekaran. Effect of seaweed extracts on the growth and biochemical constituents of Vignasinensis. Bioresource Technology. 2006;97 1745-1751

19. Abdel-Mawgoud AMR, AS Tantawy, Magda M. Hafez and Hoda A M Habib. Seaweed extract improves growth, yield and quality of different watermelon hybrids Research Journal of Agriculture and Biological Sciences. 2010;6:161-186.

20. Oliviera AKM, Ribiero JWF, Pereira KCL, Silva CAA. Effects of temperature on the germination of Diptychandra aurantiaca (Fabaceae) seeds. Journal of Agronomy 35.2013

21. Zodape ST, Abha G and Bhandari SC. Foliar application of seaweed sap as biostimulants for enhancement of Yield and Quality of Tomato. NISCAIR. CSIR.2011;25:215-219

22. Mancuso S, Azzarello E, Mugnai S, Briand X. Marine bioactive substances (IPA extract) improve ion fluxes and water stress tolerance in potted Vitis vinifera plants. Advances in Horticultural Science. 2006;20, 156-161.

23. Ortiz-Castro R, Contreras-Cornejo HA, MaciasRodriguez L, Lopez-Bucio J. The role of microbial signals in plant growth and development. Plant Signal Behav. 2009;4:701-712

24. Murray JD, Karas BJ, Sato S, Tabata S, Amyot L, Szczyglowski K. A cytokinin perception mutant colonized by Rhizobium in the absence of nodule organogenesis. Science. 2007;315:101-104. 